
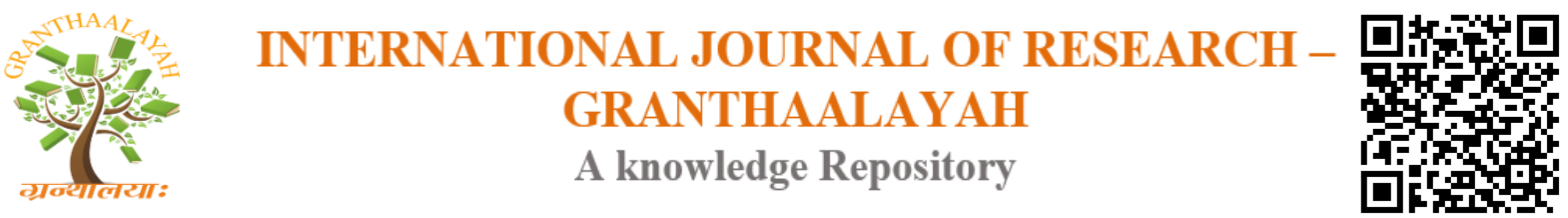

Social

\title{
EFFECTIVENESS OF E-CONTENT ON ACHIEVEMENT IN HISTORY AMONG IX STANDARD BOYS
}

\author{
J. Muthukumari ${ }^{1}$, Dr. N. Ramakrishnan ${ }^{2}$ \\ ${ }^{1}$ Ph.D. Research Scholar (Part-Time), Department of Educational Technology, Tamil Nadu \\ Teachers Education University, Chennai - 600 097, India \\ ${ }^{2}$ Professor and Head, Department of Educational Technology, Tamil Nadu Teachers Education \\ University, Chennai - 600 097, India
}

\begin{abstract}
"Educational Technology is the application of scientific knowledge about learning and the conditions of learning to improve the effectiveness and efficiency of teaching and training". The development of computer and network technology is changing the education scenario and transforming the teaching and learning process from the traditional physical environment to the digital environment. The IX Standard boys in experimental groups of both PPT design and PT design have excelled in e-content on History (the Beginning of Modern Age) than control groups which had gone through History (the Beginning of Modern Age) in traditional method in both PPT design and PT design.

Keywords: Experimental Research; Solomon Four Group Design; Descriptive Analysis; Educational Technology; E-Content; Achievement in History.

Cite This Article: J. Muthukumari, and Dr. N. Ramakrishnan. (2017). "EFFECTIVENESS OF E-CONTENT ON ACHIEVEMENT IN HISTORY AMONG IX STANDARD BOYS." International Journal of Research - Granthaalayah, 5(9:SE), 24-34. https://doi.org/10.5281/zenodo.1004556.
\end{abstract}

\section{Introduction}

Technology is used to teach a specific subject or skill directly to a student, guiding the learner through a sequence of steps involving the presentation of information, drills and exercises designed by an instructor. Teaching with technology changes the teaching and learning environment in many ways. Technology is integrating into the daily teaching curriculum which changes the implicit power structures embedded in all classroom interactions.

E content as - Digital text and images designed for display on web pages. E-content refers to an electronic content using multimedia components. E-Content differs from conventional content in many ways. E-content is technology based and technology does serve as an aid to learning. The digital contents that can be transmitted through online / offline instructional presentations, 
interactive lessons, e-Courses, virtual reality and computer supported in in-class presentation are included in the learning. The technology stimulates the learner and gets the learner involved in the learning.

\section{Statement of the Problem}

The problem has been stated as "EFFECTIVENESS OF E-CONTENT ON ACHIEVEMENT IN HISTORY AMONG IX STANDARD BOYS”.

\section{Need of the Study}

The quality of education depends to great extent on the quality of teachers. It is a known fact that quality teachers opt for an innovation in their teaching aspect through integrating technology in the classroom instruction to give the best to student. To be effective in the classroom instruction, teacher should acquire the knowledge and skills to use the new challenges in promoting innovative teaching strategies that are student-centered, collaborative, engaging, authentic, selfdirected and based on the development of higher order thinking skills with respect to handling classes for student which aim to achieve high academic standards. Education technology has great potential for improving the teaching - learning process. Educational technology is the development, application and evaluation of systems, techniques and also aids in the field of human learning. One of the important contributions of educational technology is individualized instruction, which enables is to make use of self-instruction programmers.

With the help of traditional instructional process, the teachers in general are not able to satisfy the heterogeneous group of students in learning. This problem could be overcome by the application of innovative teaching technology. In this study, individualized instruction through econtent as an alternative strategy for conventional mode. Through this method, the students are allowed to proceed and learn on this own pace, depending on his abilities and past history of achievement. Further, it motivates the students for self-learning.

\section{Objectives of the Study}

The following objective has been framed by the researcher in the present study:

- To find out the significant difference between experimental group (e-content) boys and control group (Traditional learning) boys in IX Standard students learning in (the Beginning of Modern Age) History.

\section{Hypotheses of the Study}

On the basis of the objectives of the present study the investigator framed the following hypotheses: 


\subsection{Sub hypotheses}

There is no significant difference between experimental group (e-content) boys and control group (Traditional learning) boys in IX Standard students learning in (the Beginning of Modern Age) History.

1) There is no significant difference between the pretest and post test scores of experimental group boys in PPT design.

2) There is no significant difference between the pretest scores of control group boys in PPT design and post test scores of control group boys in PPT design.

3) There is no significant difference between the pretest scores of experimental group boys in PPT design and pretest scores of control group boys in PPT design.

4) There is no significant difference between the post test scores of experimental group boys in PPT design and post test scores of control group boys in PPT design.

5) There is no significant difference between the post test scores of experimental group boys in PT design and post test scores of control group boys in PT design.

6) There is no significant difference between the pretest scores of control group boys in PPT design and post test scores of control group boys in PT design.

7) There is no significant difference between the post test scores of experimental group boys in PPT design and post test scores of experimental group boys in PT design.

8) There is no significant difference between the post test scores of control group boys in PPT design and post test scores of control group boys in PT design.

\section{Sample}

The sample of this study consisted of 50 IX standard students from two schools of Chennai and Tiruvallur Districts in Tamil Nadu. The sample was taken from Kesari Higher Secondary School, Mylapore, Chennai District and Vivekananda Matriculation Higher Secondary School, Uthukottai, Tiruvallur District in Tamil Nadu.

\section{Methodology}

The main objective of the present study was to test the effectiveness of E-Content on achievement in history among IX standard boys. In the present research experimental method was employed. Solomon Four Group design has been used.

\section{Design of the Study}

The design of the study is further explained below.

\subsection{Solomon Four Group Design}

The Solomon four group design was developed by Richard Lester Solomon mainly for the purpose of minimising the pretest sensitisation effect, which is a way of avoiding some of the difficulties associated with the pre-test and post-test design. This design contains two experimental and two control groups, which serve to reduce the influence of confounding 
variables and allow the investigator to test whether the pretest itself has an effect on the subjects. The various combinations of tested and untested groups with treatment and control groups allow the investigator to ensure that confounding variables and extraneous factors have not influenced the results. The design is given in the following table.

Solomon Four Group Design

\begin{tabular}{|l|l|l|l|}
\hline Groups & Pre-Test & Treatment & Post-Test \\
\hline Experimental Group (E1) & O & X & O \\
\hline Control Group (C1) & O & & O \\
\hline Experimental Group (E2) & & X & O \\
\hline Control Group (C2) & & & O \\
\hline
\end{tabular}

This design is a combination of the pretest-posttest control group design and the posttest only control group design. It is as good at controlling threats to internal and external validity as the posttest only control group design, but superior to that design with respect to statistical conclusion validity.

\subsection{Tools Used for the Study}

The following tools and materials were used in the present study:

1) Criterion test on history for IX standard students in the unit "The Beginning of Modern Age" was the major tool used to measure the dependent variable.

2) E-content package on history unit "The Beginning of Modern Age" a part in history from IX standard social science syllabus of Tamil Nadu Government.

\subsection{Conducting the Experiment}

The Pre and Post-tests were administrated for both Group I and Group II. The post-test only design (PPT design) was administrated for Group III and Group IV. The investigator had developed the E-Content package for the Beginning of Modern Age in IX standard History subject. The two Experimental groups' with sample of 50 students each were taken to the treatment. These students were taught with the E-Content. The two Control groups' with sample of 50 students each were taken to the regular classroom. These students were taught in the traditional way. The treatment was given for 45 minutes per day. Corrective feedback was given wherever necessary. When any point was not learnt, additional time was given and the media material was screened once again wherever necessary.

\section{Hypotheses Testing}

Hypothesis 1: There is no significant difference between experimental group (e-content) boys and control group (Traditional learning) boys in IX Standard students learning in (the Beginning of Modern Age) History.

The investigator in order to test the above hypothesis follows the following design of analysis as recommended for Solomon four group design. 

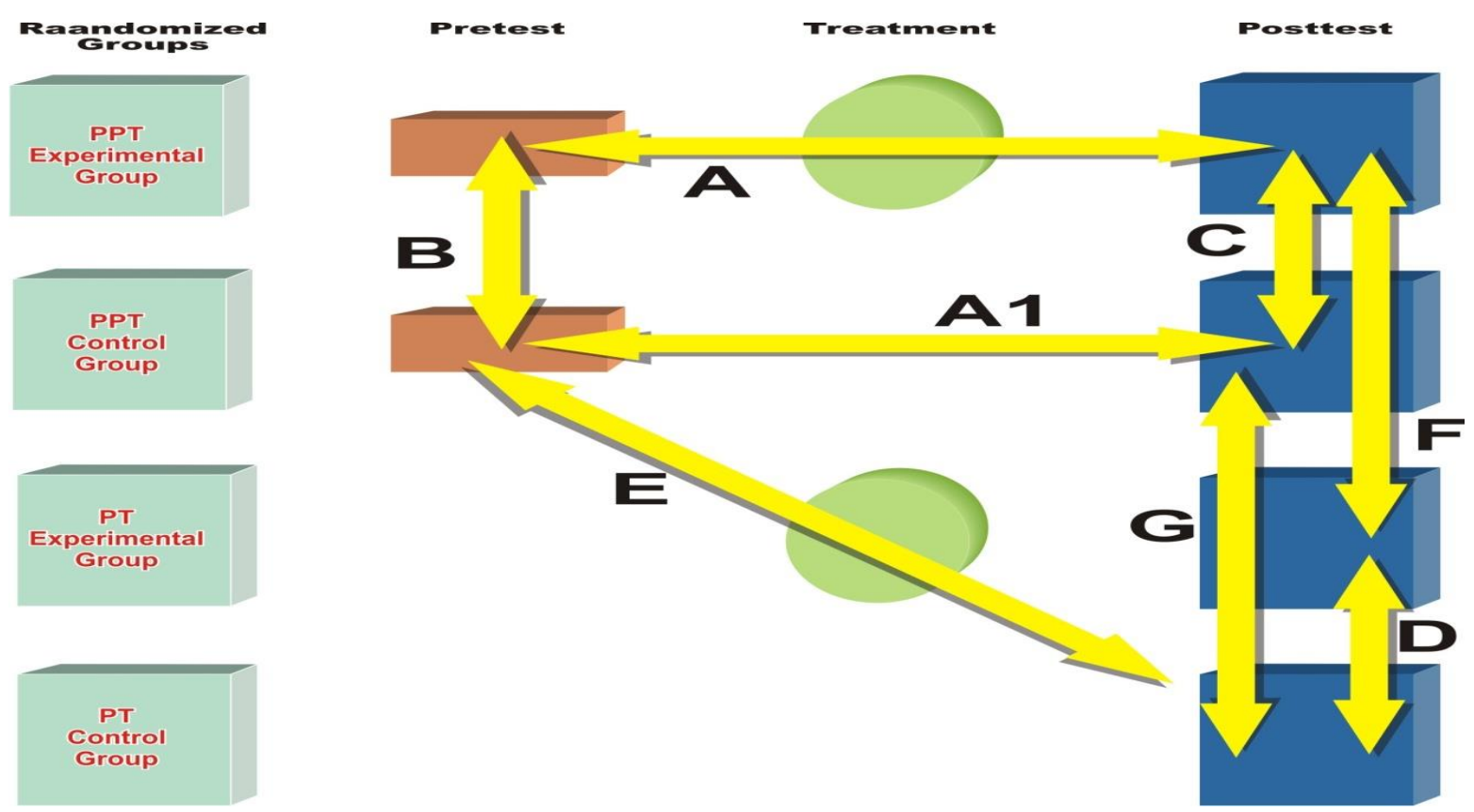

Figure 1: Solomon Four Group Experimental Design

Sub Hypothesis 1.1: There is no significant difference between the pretest and post test scores of experimental group boys in PPT design.

Table 1: N, Mean and S.D. Values for the Pre Test and Post Test Scores of Experimental Group Boys in Ppt Design

\begin{tabular}{|l|l|l|l|l|l|}
\hline Variables & N & Mean & S.D. & T & Significance \\
\hline $\begin{array}{l}\text { PPT (Experimental Boys) } \\
\text { - Pre Test }\end{array}$ & 12 & 19.17 & 4.707 & 13.496 & $\begin{array}{l}\text { Significant for the } \\
\text { df of 22 at } 0.05 \\
\text { level (2.074) }\end{array}$ \\
\hline $\begin{array}{l}\text { PPT (Experimental Boys) } \\
\text { - Post Test }\end{array}$ & 12 & 45.00 & 8.485 & & \\
\hline
\end{tabular}

It is evident from the above table that that ' $t$ ' value found out is 13.496. It is higher than the critical value of 2.074 at 0.05 level. It is significant. Hence, it can be concluded that there exists significant difference between the pretest and post test scores of experimental group boys in the PPT design. The mean value of the posttest (45.00) scores of experimental group boys in PPT design is higher than the mean value of pretest (19.17) scores of experimental group boys in PPT design. So, the hypothesis stated is rejected. The experimental group boys in PPT design has performed well after the experiment. It can be interpreted that e-content on the Beginning of Modern Age has had a good impact on IX standard boys' students learning of the Beginning of Modern in PPT design.

Sub Hypothesis 1.2: There is no significant difference between the pretest scores of control group boys in PPT design and post test scores of control group boys in PPT design. 
Table 2: N, Mean and S.D. Values for the Pre Test Scores of Control Group Boys in Ppt Design And Post Test Scores of Control Group Boys in Ppt Design

\begin{tabular}{|c|c|c|c|c|c|}
\hline Variables & N & Mean & S.D. & T & Significance \\
\hline $\begin{array}{c}\text { PPT (Control Boys) - Pre } \\
\text { Test }\end{array}$ & 13 & 19.31 & 6.921 & \multirow{2}{*}{14.576} & $\begin{array}{c}\text { Significant for the } \\
\text { df of 24 at 0.05 } \\
\text { level (2.064) }\end{array}$ \\
\hline $\begin{array}{c}\text { PPT (Control Boys) - } \\
\text { Post Test }\end{array}$ & 13 & 38.23 & 8.497 & & . \\
\hline
\end{tabular}

It is evident from the above table that that ' $t$ ' value found out is 14.576 . It is higher than the critical value of 2.064 at 0.05 level. It is significant. Hence, it can be concluded that there exists significant difference between the pretest scores of control group boys in PPT design and post test scores of control group boys in PPT design. The mean value of the posttest (38.23) scores of control group boys in PPT design is higher than the mean value of pre test (19.31) scores of control group boys in PPT design. So, the hypothesis stated is rejected. The pretest scores of control group boys in PPT design is lesser than the post test scores of control group boys in PPT design.

Sub Hypothesis 1.3: There is no significant difference between the pretest scores of experimental group boys in PPT design and pretest scores of control group boys in PPT design.

Table 3: N, Mean and S.D. Values for the Pre Test Scores of Experimental Group Boys in Ppt Design and Pre Test Scores of Control Group Boys in Ppt Design

\begin{tabular}{|c|c|c|c|c|c|}
\hline Variables & N & Mean & S.D. & T & Significance \\
\hline $\begin{array}{c}\text { PPT (Experimental Boys) } \\
- \text { Pre Test }\end{array}$ & 12 & 19.17 & 4.707 & \multirow{2}{*}{0.092} & $\begin{array}{c}\text { Not significant for } \\
\text { the df of } 22 \text { at } \\
0.05 \text { level (2.074) }\end{array}$ \\
\cline { 1 - 4 } $\begin{array}{c}\text { PPT (Control Boys) - Pre } \\
\text { Test }\end{array}$ & 12 & 19.42 & 7.217 & & \\
\hline
\end{tabular}

It is evident from the above table that ' $t$ ' value found out is 0.092 . It is lower than the critical value of 2.074 at 0.05 level. It is not significant. Hence, it can be concluded that there exists no significant difference between the pretest scores of experimental group boys in PPT design and pretest scores of control group boys in PPT design. So, the hypothesis stated is accepted. It can be interpreted that the experimental group boys in PPT design and control group boys in PPT design are equated exactly.

Sub Hypothesis 1.4: There is no significant difference between the post test scores of experimental group boys in PPT design and post test scores of control group boys in PPT design.

Table 4: N, Mean and S.D. Values for the Post Test Scores of Experimental Group Boys in Ppt Design and Post Test Scores of Control Group Boys in Ppt Design

\begin{tabular}{|c|c|c|c|c|c|}
\hline Variables & N & Mean & S.D. & T & Significance \\
\hline $\begin{array}{c}\text { PPT (Experimental Boys) } \\
- \text { Post Test }\end{array}$ & 12 & 45.00 & 8.485 & 2.036 & $\begin{array}{c}\text { Not significant for } \\
\text { the df of } 22 \text { at } \\
0.05 \text { level (2.074) }\end{array}$ \\
\hline $\begin{array}{c}\text { PPT (Control Boys) }- \\
\text { Post Test }\end{array}$ & 12 & 38.08 & 8.857 & & 0.057 \\
\hline
\end{tabular}


It is evident from the above table that ' $t$ ' value found out is 2.036. It is lower than the critical value of 2.074 at 0.05 level. It is not significant. Hence, it can be concluded that there exists no significant difference between the post test scores of experimental group boys in PPT design and post test scores of control group boys in PPT design. So, the hypothesis stated is accepted. It can be interpreted that the experimental group boys in PPT design and control group boys in PPT design are equated exactly.

Sub Hypothesis 1.5: There is no significant difference between the post test scores of experimental group boys in PT design and post test scores of control group boys in PT design.

Table 5: N, Mean and S.D. Values for the Post Test Scores of Experimental Group Boys in Pt Design and Post Test Scores of Control Group Boys in Pt Design

\begin{tabular}{|l|l|l|l|l|l|}
\hline Variables & N & Mean & S.D. & T & Significance \\
\hline $\begin{array}{l}\text { PT (Experimental Boys) } \\
- \text { Post Test }\end{array}$ & 12 & 45.42 & 6.331 & 3.796 & $\begin{array}{l}\text { Significant for the } \\
\text { df of 22 at 0.05 } \\
\text { level (2.074) }\end{array}$ \\
\hline $\begin{array}{l}\text { PT (Control Boys) - Post } \\
\text { Test }\end{array}$ & 12 & 34.08 & 7.115 & & \\
\hline
\end{tabular}

It is evident from the above table that that ' $t$ ' value found out is 3.796. It is higher than the critical value of 2.074 at 0.05 level. It is significant. Hence, it can be concluded that there exists significant difference between the post test scores of experimental group boys in PT design and post test scores of control group boys in PT design. The mean value of the posttest (45.42) scores of experimental group boys in PT design is higher than the mean value of pretest (34.08) scores of control group boys in PT design. So, the hypothesis stated is rejected. The post test scores of control group boys in PT design is lesser than the post test scores of experimental group boys in PT design.

Sub Hypothesis 1.6: There is no significant difference between the pretest scores of control group boys in PPT design and post test scores of control group boys in PT design.

Table 6: N, Mean and S.D. Values for the Pre Test Scores of Control Group Boys in Ppt Design And Post Test Scores of Control Group Boys in Pt Design

\begin{tabular}{|l|l|l|l|l|l|}
\hline Variables & N & Mean & S.D. & T & Significance \\
\hline $\begin{array}{l}\text { PPT (Control Boys) - Pre } \\
\text { Test }\end{array}$ & 12 & 19.42 & 7.217 & 5.249 & $\begin{array}{l}\text { Significant for the } \\
\text { df of 22 at } 0.05 \\
\text { level (2.074) }\end{array}$ \\
\hline $\begin{array}{l}\text { PT (Control Boys) - Post } \\
\text { Test }\end{array}$ & 12 & 34.08 & 7.115 & 5 & \\
\hline
\end{tabular}

It is evident from the above table that the ' $t$ ' value found out is 5.249. It is higher than the critical value of 2.074 at 0.05 level. It is significant. Hence, it can be concluded that there exists significant difference between the pretest scores of control group boys in PPT design and post test scores of control group boys in PT design. The mean value of the posttest (34.08) scores of control group boys in PT design is higher than the mean value of pre test (19.42) scores of control group boys in PPT design. So, the hypothesis stated is rejected. The pretest scores of control group boys in PPT design is lesser than the post test scores of control group boys in PT design. 
Sub Hypothesis 1.7: There is no significant difference between the post test scores of experimental group boys in PPT design and post test scores of experimental group boys in PT design.

Table 7: N, Mean and S.D. Values for the Post Test Scores of Experimental Group Boys in Ppt Design and Post Test Scores of Experimental Group Boys in Pt Design

\begin{tabular}{|l|l|l|l|l|l|}
\hline Variables & N & Mean & S.D. & T & Significance \\
\hline $\begin{array}{l}\text { PPT (Experimental Boys) } \\
- \text { Post Test }\end{array}$ & 12 & 45.00 & 8.485 & 0.138 & $\begin{array}{l}\text { Not significant for } \\
\text { the df of 22 at } \\
0.05 \text { level (2.074) }\end{array}$ \\
\hline $\begin{array}{l}\text { PT (Experimental Boys) } \\
- \text { Post Test }\end{array}$ & 12 & 45.42 & 6.331 & & 0.42 \\
\hline
\end{tabular}

It is evident from the above table that' ${ }^{\prime}$ ' value found out is 0.138 . It is lower than the critical value of 2.074 at 0.05 level. It is not significant. Hence, it can be concluded that there exists no significant difference between the post test scores of experimental group boys in PPT design and post test scores of experimental group boys in PT design. So, the hypothesis stated is accepted. It can be interpreted that the experimental group boys in PPT design and experimental group boys in PT design are equated exactly.

Sub Hypothesis 1.8: There is no significant difference between the post test scores of control group boys in PPT design and post test scores of control group boys in PT design.

Table 8: N, Mean and S.D. Values for the Post Test Scores of Control Group Boys in Ppt Design and Post Test Scores of Control Group Boys in Pt Design

\begin{tabular}{|l|l|l|l|l|l|}
\hline Variables & N & Mean & S.D. & T & Significance \\
\hline $\begin{array}{l}\text { PPT (Control Boys) - } \\
\text { Post Test }\end{array}$ & 12 & 38.08 & 8.857 & 1.228 & $\begin{array}{l}\text { Not significant for } \\
\text { the df of 22 at } \\
0.05 \text { level (2.074) }\end{array}$ \\
\hline $\begin{array}{l}\text { PT (Control Boys) - Post } \\
\text { Test }\end{array}$ & 12 & 34.08 & 7.115 & & \\
\hline
\end{tabular}

It is evident from the above table that ' $t$ ' value found out is 1.228 . It is lower than the critical value of 2.074 at 0.05 level. It is not significant. Hence, it can be concluded that there exists no significant difference between the post test scores of control group boys in PPT design and post test scores of control group boys in PT design. So, the hypothesis stated is accepted. It can be interpreted that the control group boys in PPT design and control group boys in PT design are equated exactly

\begin{tabular}{|c|c|c|}
\hline Variable & Significance & Remarks \\
\hline PPT(Experimental) - Pre Test & \multirow{2}{*}{ Significant } & $\begin{array}{l}\text { PPT(Experimental) }- \text { Pre Test } \\
<\end{array}$ \\
\hline PPT(Experimental) - Post Test & & PPT(Experimental)-Post Test \\
\hline PPT(Control) - Pre Test & \multirow{2}{*}{ Significant } & PPT(Control)-Pre Test \\
\hline PPT(Control) - Post Test & & PPT(Control)-Post Test \\
\hline PPT(Experimental) - Pre Test & Not & PPT(Experimental)-Pre Test \\
\hline
\end{tabular}




\begin{tabular}{|c|c|c|}
\hline PPT(Control) - Pre Test & Significant & $\begin{array}{l}= \\
\text { PPT }(\text { Control)-Pre Test }\end{array}$ \\
\hline PPT(Experimental) - Post Test & \multirow{2}{*}{$\begin{array}{l}\text { Not } \\
\text { Significant }\end{array}$} & PPT(Experimental)-Post Test \\
\hline PPT(Control) - Post Test & & PPT(Control)-Post Test \\
\hline PT(Experimental) - Post Test & \multirow{2}{*}{ Significant } & PT(Experimental)-Post Test \\
\hline PT(Control) - Post Test & & PT(Control)-Post Test \\
\hline PPT(Control) - Pre Test & \multirow{2}{*}{ Significant } & PPT(Control)-Pre Test \\
\hline PT(Control) - Post Test & & PT(Control)-Post Test \\
\hline PPT(Experimental) - Post Test & \multirow{2}{*}{$\begin{array}{l}\text { Not } \\
\text { Significant }\end{array}$} & $\begin{array}{l}\text { PPT(Experimental)-Post Test } \\
=\end{array}$ \\
\hline PT(Experimental) - Post Test & & PT(Experimental)-Post Test \\
\hline PPT(Control) - Post Test & \multirow{2}{*}{$\begin{array}{l}\text { Not } \\
\text { Significant }\end{array}$} & PPT(Control)-Post Test \\
\hline PT(Control) - Post Test & & $\overline{\text { PT}}$ (Control)-Post Test \\
\hline
\end{tabular}

Chart 1: Chart Showing the Solomon Four Group Analysis - Boys

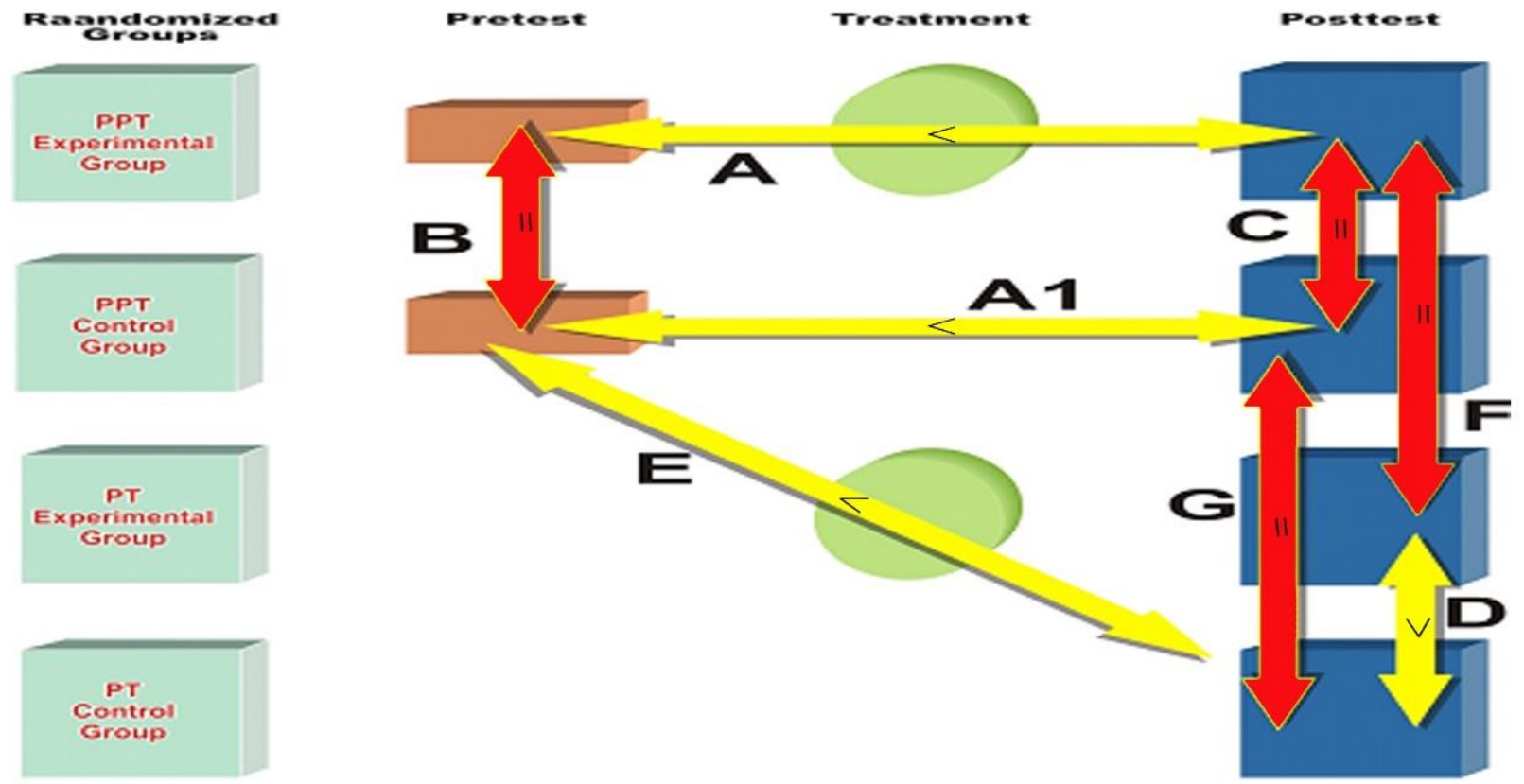

Figure 2: Graph Showing the Solomon Four Group Analysis - Boys

A - PPT Experimental Group pre test (vs) PPT Experimental Group post test

A1 - PPT Control Group pre test (vs) PPT Control Group post test

B - PPT Experimental Group pre test (vs) PPT Control Group pre test

C - PPT Experimental Group post test (vs) PPT Control Group post test

D - PT Experimental Group post test (vs) PT Control Group post test

E- PPT Control Group pre test (vs) PT Control Group post test 
F - PPT Experimental Group post test (vs) PT Experimental Group post test

$\mathrm{G}-\mathrm{PPT}$ Control Group post test (vs) PT Control Group post test

\section{Findings of the Study}

The major findings of the study are as follows:

It is evident from the findings that the IX standard boys in experimental group of PT design are excelled in e-content on History (the Beginning of Modern Age) than control groups which had gone through History (the Beginning of Modern Age) in traditional method in PT design. (Vide Table 5)

It is evident from the findings that the post test scores of IX standard boys in both experimental and control groups PPT design are higher than their pre test scores in PPT design. It implies that both e-content and traditional method have had an impact on IX standard boys' learning of History (the Beginning of Modern Age). (Vide Table $1 \&$ 2)

It is proved from the findings that the pre test scores of IX standard boys in both experimental and control groups of PPT design are equal. It implies that IX standard boys in both experimental and control groups are equal in their academic achievement. The researcher has properly equated the groups. (Vide Table 3)

It is proved from the findings that the post test scores of IX standard boys in both experimental and control groups of PPT design are equal. It implies that IX standard boys in both experimental and control groups are equal in their academic achievement. The researcher has properly equated the groups. (Vide Table 4)

A cross comparison of the findings reveals that the post test scores of IX standard boys in control group of PT design are higher than the pre test scores of IX standard boys in control group of PPT design. It implies that the traditional teaching has had an effect on IX standard boys' learning of History (the Beginning of Modern Age). (Vide Table 6)

It is proved from the findings that the post test scores of IX standard boys in control group of PPT design and the post test scores of IX standard boys in control group of PT design are equal. (Vide Table 8) In the same way, the post test scores of IX standard boys in experimental group of PPT design and the post test scores of IX standard boys in experimental group of PT design are equal. (Vide Table 7) It implies that IX standard boys in both experimental and control groups are equal in their academic achievement. The researcher has properly equated the groups.

\section{Conclusion}

The IX Standard boys in experimental groups of both PPT design and PT design have excelled in e-content on History (the Beginning of Modern Age) than control groups which had gone through History (the Beginning of Modern Age) in traditional method in both PPT design and PT design. It may be concluded that use of E-Content way of teaching has significant impact on enhancing the achievement in history among the IX standard boys. 


\section{Reference}

[1] Aggarwal, J. C. (1996). Teaching of History. New Delhi, Vikas Publishing House Pvt. Ltd.

[2] Ajai S. Gaur. \& Sanjaya S. Gaur, (2006). Statistical Methods for Practice and Research (A Guide to Data Analysis Using SPSS). New Delhi, SAGE Publications India Pvt Ltd.

[3] Arora, K. L. (2006). Teaching of History. Ludhiana, Tandon Publications, p1-2.

[4] Best W. John. \& Kahn V. James. (2014). Research in Education. Delhi, PHI Learning Private Limited,

[5] Durga Padhiyarm, (2014). Educational Technology. New Delhi, Cyber Tech Publication, p1.

[6] Francis, A. T., \& Susan Mathew, K. (2014). Library and Web Tools for E-learning and Teaching. New Delhi, Authors press.

[7] Golden, S. A. R. (2011). Problems and Prospectus of Distance Education. Quality Enhancement in Distance Education for Life Long Learning, 1(1), 343-344.

[8] Golden, S. A. R. (2016). Rural Students'attitude towards English as Medium of Instruction in Higher Education-An Analysis. International Journal of Research, 3, 1-10.

[9] Golden, S. A. R. (2017). Attitude of Students and Teachers towards E-Learning-An Analysis. Recent Research in Social Science \& Humanities, 1, 5-10.

[10] Golden, S. A. R. (2017). Recent Research in Social Sciences \& Humanities. EduPedia Publications (P) Ltd.

[11] Gupta, S. P. (1969). Statistical Methods. New Delhi, Sultan Chand \& Sons.

[12] Henry E. Garrett, (2014). Statistics in Psychology and Education. Delhi, Surjeet Publications.

[13] Kothari, C. R., \& Gaurav Garg, (2014). Research Methodology, Methods and Techniques. New Delhi, New Age International Publishers.

[14] Kulbir Singh Sidhu, (1984). Methodology of Research in Education. New Delhi, Sterling Publishers Private Limited.

[15] Lakshmi Shanmugam, P. N. (Jan - Mar 2014). A Study of Digital Smart Classroom Teaching Experience of High School Techers in Madural District. Journal of Educational Research \& Extension, ISSN 0973 - 6190, v51 (1), p27-31.

[16] Mangal, S. K. (2016). Statistics in Psychology and Education. Delhi, PHI Learning Private Limited.

[17] Nagarajan, K., Srinivasan, R., \& Mary Vijayakumar, (1994). Research Methodology in Education. Chennai, Ram Publishers.

[18] Narayan Dash Biranchi, (2003). Teaching of History. Hyderabad, Neelkamal Publications Pvt. Ltd.

[19] Regi, S. B., \& Golden, S. A. R. (2014). A Study on Educational Loan Availed By Students in Trichy City. Journal of International Academic Research for Multidisciplinary (Jiarm), 2 (1).

[20] Text Book for Standard Nine, (2013). TamilNadu Textbook Corporation. Chennai.

[21] Thakur, K. R. (2010). Educational Development and Technology. New Delhi, Saurabh Publishing House. 